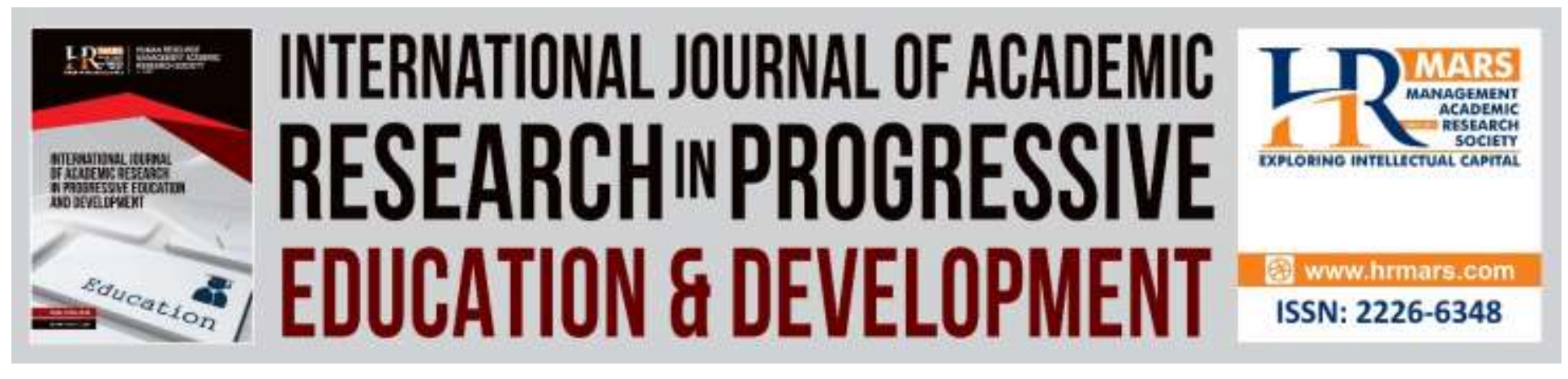

\title{
Cluster Schools of Excellence: Concept and Implementation
}

\author{
Maizatul Suraya Muhammad Nor, Mohd Isa Hamzah, Khadijah Abdul Razak
}

To Link this Article: http://dx.doi.org/10.6007/IJARPED/v8-i3/6296

DOI: 10.6007/IJARPED/v8-i3/6296

Received: 10 July 2019, Revised: 19 August 2019, Accepted: 03 September 2019

Published Online: 22 September, 2019

In-Text Citation: (Nor, Hamzah, \& Razak, 2019)

To Cite this Article: Nor, M. S. M., Hamzah, M. I., \& Razak, K. A. (2019). Cluster Schools of Excellence: Concept and Implementation. International Journal of Academic Research in Progressive Education and Development, $8(3), 118-125$.

Copyright: (C) 2019 The Author(s)

Published by Human Resource Management Academic Research Society (www.hrmars.com)

This article is published under the Creative Commons Attribution (CC BY 4.0) license. Anyone may reproduce, distribute, translate and create derivative works of this article (for both commercial and non-commercial purposes), subject to full attribution to the original publication and authors. The full terms of this license may be seen

at: http://creativecommons.org/licences/by/4.0/legalcode

Vol. 8(3) 2019, Pg. 118 - 125

http://hrmars.com/index.php/pages/detail/IJARPED

JOURNAL HOMEPAGE

Full Terms \& Conditions of access and use can be found at http://hrmars.com/index.php/pages/detail/publication-ethics 


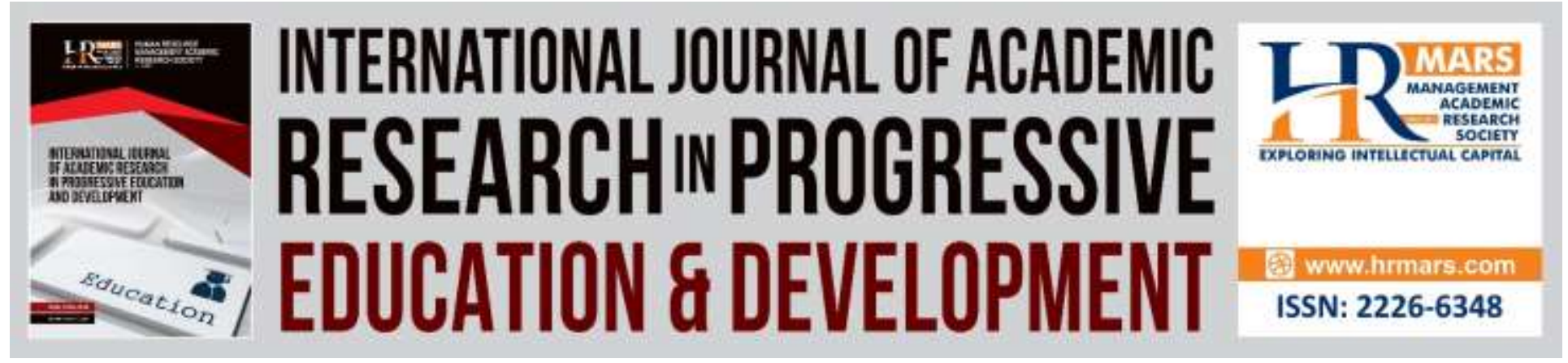

\title{
Cluster Schools of Excellence: Concept and Implementation
}

\section{Maizatul Suraya Muhammad Nor, Mohd Isa Hamzah, Khadijah Abdul Razak}

Faculty of Education, The National University of Malaysia

\begin{abstract}
This article is based on the past researches related with the Cluster Schools of Excellence which has built under the Fundamental Scheme of the Foundation Education (PIPP 2006-2010). It also talks about the concept of Cluster School that coversits background, characteristics, implementation and past researches on its intensity of academic performance. Some further researches are necessary to cultivate its interest and trail to successfully encourage them with respect to the vision and mission of the Ministry of Education Malaysia which is boosting the excellence of education institution.
\end{abstract}

Keywords: Cluster School, Excellence, Concept and Implementation

\section{Introduction}

In the ninth of Malaysian Scheme, the purpose of education is to nurture youngsters to be elite and global minded. Having this plan, the Foundation of Education Scheme is introduced by the theme of Innovation: National Mission of Unity. From PIPP 2006-2010, the foundation of education is based on six strategic fundamentals yet the government encourages its success with the last one by forming clusters such as academic, curriculum, sport and other specialties then absorbs them into some famous abroad institutions (Nordin \& Othman, 2008).

\section{The Background of Cluster Schools of Excellence}

In early 2006, meanwhile a local press conference on 29 April 2009, the former Education Minister, YB Dato' Seri Hishamuddin bin Tun Hussein declared to grant every school its own autonomy. The reason why it has to be done because to let the school administration manages programs and activities that get well with its own condition (Sim \& Azmiza, 2012). Having that hope, on 19 Januari 2007 a Proposal of Concept and Implementation Cluster Schools of Excellence was proposed by the Division of Planning and Research of Education Policy (BPPDP, 2007), Ministry of Education of Malaysia (KPM) in The Conference of Professional Affairs KPM No. 1/2007. The implementation Cluster Schools of Excellence had been under the authority of the Main Scheme of Education Foundation (PIPP) since 2006-2010 and widely advertised to the 
whole country. The purpose of the existence of the school is supporting on upgrading education institution as stated in the sixth fundamental of the Fundamental Scheme of Education Foundation (PIPP) 2006-2010 so as a "showcase" for international views and a scale grading for typical schools. At the time of Tan Sri Alimuddin served as a Vice-President of Education of Malaysia, he stated on Utusan (2007) that the Clusters are the best schools of them all. Even though they were in some particular categories of either in rural or specified for Aboriginals, they were chosen and gifted with autonomies. He added that the aspect of autonomy in the curriculum was consisted in the way of how it is presented, the evaluation of the student's approach, progression, reporting student's performance, timetable, interaction in the class, the duration of its implementation, the national examination subjects(out of the cores of the national curriculum) and others. One of the leading aspects of the implementation of Cluster School is from the management of school orientation. By doing this, Cluster Schools have more authority to lead their schools from the sources of human beings to the assets through the new intakes (Ministry of Education Malaysia, 2006). Meantime, from Nordin \& Othman (2008), Cluster School is not to be recognized as the best school in the country but its existence for upgrading the quality of education and boosting school performance in national education. The existence of a Cluster School as a role model of its kind in the same cluster and the others.

\section{The Characteristics of Cluster Schools of Excellence}

The selection of it is decided by the Ministry of Education Malaysia. There are three committees to build the concept of Cluster School:

(i) The Committee of School Selection- the President of Ministry of Education of Malaysia as a chairman.

(ii) The Panel of Advisers- Tan Sri Panglima Dr. Abdul Rahman Arshad as a chairman.

(iii) The Executive Committee- Vice-President of Malaysian Education Malaysia as a chairman (School Department).

(Ministry of Education Malaysia, 2006).

The implementation of Cluster School is based on decentralization process which involves in the ability of a school by the granted management autonomy. There are acceptable "Stakeholder" opinions like PIBG, Alumni, school administration and teachers for the implementation of Cluster School. The Panel of Advisers will also let their intelligence to be lent to get rest assured that the implementation is successfully well done. Moreover, the right autonomy from the perspective of human resource which includes;
a. teacher selection
b. fixing practicing system
c. selection and development of protégé
d. selection of a group of new student's base on "niche area"
e. sharing skills in and among clusters, and more.

(Utusan, 2007) 
Vol. 8, No. 3, 2019, E-ISSN: 2226-6348 @ 2019 HRMARS

A Cluster School has an evergreen element "niche area" that ables to produce a high-class employee competing with the global demand next as a show case for both national and international levels. There are three standards for an Excellence Cluster School that shows in the standard $A$; an excellent school model as well as a showcase that able to compete with international level, the standard $B$; is also an excellent school model and champion in the national level, extend to the international level, and at the standard C; as a potential school earns excellency in the national level (the Management of Boarding and Excellent Schools of the Ministry of Education Malaysia). On the other hand, the relationship between Cluster School and high institution of education also realized in the implementation of adopted school. For instance ,the Islamic Science University of Malaysia (USIM) mandated to 16 Cluster Schools as its adopted schools (Utusan, 2012).

\section{The Implementation Cluster Schools of Excellence}

A chosen school with a status of a Cluster School needs to meet some requirements to get assured of qualification cluster schools of excellence.

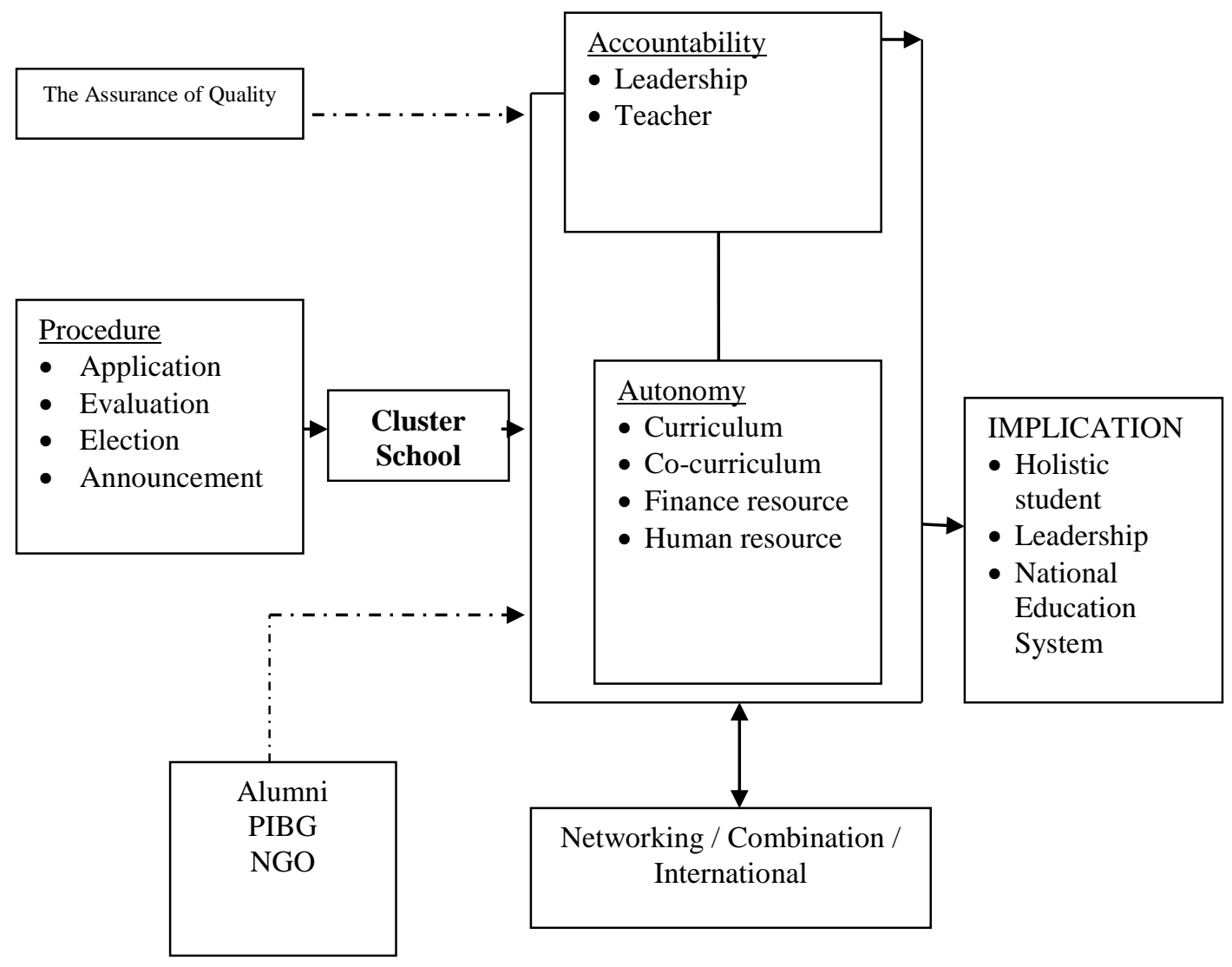

Figure 1: Diagrams a Conceptual Framework of the Principles of a Cluster School Source: A Model of a Cluster School (BPPDP, 2007). 
Vol. 8, No. 3, 2019, E-ISSN: 2226-6348 @ 2019 HRMARS

From the above diagram 1, it shows that a school which meets the requirements from the Ministry of Education Malaysia could extend their application to the obliged KPM. Then, the process of the school assessment is applied by the instrumentation of SKPM and Annex. The optional of the school is decided by the Executive Committee of the cluster School (JK) and in the end, advertised by the Minister of Education (YB). On the contrary, the administration of Cluster School would be evaluated on the aspect of accountability in leadership as it is referring to the "key performance indicator" (KPI) and at the same time, the requirement of the teachers should be reached the criteria as a whole excellent teacher. Their performance also would contribute their sustainable career in a Cluster School. Meanwhile to ensure the school is continuously enhancing its level of quality, the inside-out elements its guardian is applied (Ministry of Education Malaysia, 2006). Other than that, a Cluster School has an autonomy in some fields like curriculum, co-curriculum, fundamental of finance and human resources. The management should be rightfully trusted to lead the school in the way they like without intervene of a tight rein on them by the Department of Education nor the Local Official of Education (PPD). The involvement of school alumni, PIBG and NGO's institutions is strongly recommended in the school especially in such aspects as scholarship, finance/donation; improving academic performance program; enhancing co-curriculum activities and career consultancy. Whereas, another similar program is also conducted by the school which is a networking or an interconnection among some regional schools. There are several running activities during the program;

Table 1. The Interconnection Program Cluster Schools of Excellence The Framework of the Interconnection Cluster Schools of Excellence (SKK)

\begin{tabular}{c} 
Conference/Seminar/Camp \\
Exchangeable of Student and Teacher \\
Culture of Talent-time \\
Academic andCo-curriculum Contests \\
International Examination \\
Paperwork Presentation / "Best Practices" \\
\hline
\end{tabular}

(Source: The Ministry of Education Malaysia, 2006)

The born Cluster Schools of Excellence, gives positive effect to the development of national education that accelerates the achievement education institutions in Malaysia (Ministry of Education Malaysia, 2006).

\section{Past Researches}

A case has been done in Aminuddin Baki Secondary School of Kuala Lumpur that concluded as the brand new school named as a Cluster School brought forth the excellence of the school in Malaysian Education System. The faith of KPM is spreading fully potential of education institutions that encouraging teachers and student's talents on behalf of the name of national education and its system to the international level with fame by realizing the brand new schools as Clusters. It proves the competency of KPM in building education system alike international 
standard and next producing talented employees that meet the global demands (Mahfod \& Akmal, 2009). Ismail \& Abdullah (2011) has proved that the purpose of Cluster Schools in Malaysia is not only focus on increasing the excellent of its organization but also works to earn multi-needs such as talents and capabilities for their students and staff. From their outcomes show that the element of evergreen in every Cluster School plays important role to successfully grow students' performance. According to Bahagian Perancangan Penyelidikan Dasar Pendidikan (2007), the implementation of Cluster School has two dimensions. the first dimension consists of students and school climate. From the student aspect, the characteristics of its excellence are involved in three factors which are academic, co-curriculum and moral. While the management aspect should have had effective visions, another aspect of fundamental development should be manageable and applied optimally with the effectiveness of teaching aspect. The school has to be conducive for students and leaders supposedly put quality on the top of their leadership. Meanwhile, the second dimensionis about an accountability of the school which makes the leader to be responsible towards his school performance.

Moreover, Ismail \& Abdullah (2011) researches shows that there are many ways to upgrade students' potential and talent in a cluster school program especially in the evergreen field.They are granted with autonomy to realize it by dealing with programs and activities, consult with outside teachers and specialists to catalyze the excellency of their student in earning the evergreen field, by doing cooperation with local and international higher institutions and develop their teachers' professionalism.

From the researches by Salleh et.al., (2009), states that the Islamic College of Sultan Alam Shah (KISAS) has proved their excellency as a Cluster School by taking part in competitions. Some of the best achievements of their students were in year 2007 from the consistency of outstanding performance in Arabic linguistic as the second place for "Qiraah Sab'ah", and the third in Arabic quiz at the national level. Furthermore, in the field of public speaking, the students of KISAS were champions for the state competition of the Royal Trophy Speech "Pidato Piala Di Raja"while excelling in co-curriculum as the third place in the Championship of Klang Schools for Martial Arts "Kejohanan Pencak Silat Sekolah-sekolah Klang". All these proved that Cluster Schools have done very well for their students' performances in both fields of curriculum and co-curriculum.

In Aiping, (2007) has found out two big challenges that caused failure in the implementation of Cluster School in Namibia were lack of supporting system and sources.In addition to that, there is a lot of researches related with Cluster School but preferred for leadership in details. One of them is from Burstow's (2009) research that analyzed about a cohort of headmasters of Malaysians secondary schools for those were sent to the United Kingdom for a course then found out the difference between language and context as a barrier of the issues they have been experienced there. Otherwise, Fiona Dwyer repeated the statement from a headmaster of Mataroa school which tells that headmasters in di Taihape have faced a big challenge to deal with preferring the successful of school administration or the leadership of education. However, building a Cluster School is a chance for many headmasters to share issues and discuss on how to overcome every obstacle as it gives spaces for information, specialties and 
the best implementation among schools (Dwyer, 2018) as stated in Sim \& Azmiza (2012). By referring from the past researches, it is plain that a Cluster School has its own "niche area" which differs with typical daily school. Unlike others, The elected leaders in a Cluster School have autonomy to lead the school.

\section{In Conclusion}

As a conclusion, the existence of a Cluster School is part of the Scheme of Foundation Education (PIPP) 2006-2010 as the latest initiative to improve the excellency in all aspects such as academic, co-curriculum and administration.

\section{References}

Nordin, A. B. \& Othman, I. (2008). Falsafah Pendidikan Dan Kurikulum edisi kedua. Quantum Books.

Aiping, L., P. (2007). Cluster Centre Principals' Perceptions of the Implementation of the School Cluster System in Namibia. Unpublished Master's Thesis. Grahamstown : Rhodes University.

Ismail, A. and Abdullah, A. G. (2011). Cluster Schools for Diverse Students needs in Malaysia : A System View. International Journal of Education 3(2). P. 1-13.

BPPDP. (2007). Kertas Cadangan Konsep dan Pelaksanaan Kelompok Sekolah Cemerlang.

Burstow, B. (2009). Effective Professional Development as Cultural Exchange. Opportunities Offered By Visits of Headteacher Groups from Malaysian to the UK. Teacher development, (13(4) p. 349-361.).

Dwyer F. (2009). Taihape Principals' Cluster : Principles Working Together to Enhance Their Own practice.

Kementerian Pelajaran Malaysia. (2006). Pelan Induk Pembangunan Pendidikan. Putrajaya KPM.

Salleh, M. J., Omar, D. F. M. \& Ramli, R. (2009). Menjana modal insan kamil model "Jerisah" : Kajian kes di Kolej Islam Sultan Alam Shah. In Wacana Pendidikan Islam kali ke 7 UKM : Gontor, Indonesia.

Nor, M. S. M., Hamzah, M. I., \& Razak, K. A. (2019). Cluster Schools of Excellence: Concept and Implementation. International Journal of Academic Research in Progressive Education and Development, 8(3), 118-125.

Utusan. (April). USIM pilih 16 Sekolah Kluster angkat.

Utusan. (2007, March). Sekolah Kluster Milik Rakyat.

\section{Corresponding Author}

Maizatul Suraya binti Muhammad Nor, Faculty of Education, National University of Malaysia, 43600 UKM, Bangi Selangor. surayaukm@gmail.com 